\title{
Aspidosperma (Apocynaceae) plant cytotoxicity and activity towards malaria parasites. Part I: Aspidosperma nitidum (Benth) used as a remedy to treat fever and malaria in the Amazon
}

\author{
Julia Penna Coutinho, ${ }^{1,2}$, Anna Caroline Campos Aguiar, ${ }^{1,2}$, Pierre Alexandre dos Santos ${ }^{3}$, \\ Joaquim Corsino Lima ${ }^{4}$, Maria Gabrielle Lima Rocha', Carlos Leomar Zani', \\ Tânia Maria Almeida Alves ${ }^{1}$, Antônio Euzébio Goulart Santana ${ }^{5}$, \\ Maria de Meneses Pereira ${ }^{3}$, Antoniana Ursine Krettli, ${ }^{1 / 2}$
}

\begin{abstract}
${ }^{1}$ Centro de Pesquisas René Rachou-Fiocruz, Belo Horizonte, MG, Brasil 2Programa de Pós-Graduação em Medicina Molecular, Faculdade de Medicina, Universidade Federal de Minas Gerais, Belo Horizonte, MG, Brasil ${ }^{3}$ Faculdade de Ciências Farmacêuticas, Universidade Federal do Amazonas, Manaus, AM, Brasil ${ }^{4}$ Departamento de Farmacologia, Universidade Federal do Mato Grosso, Cuiabá, MT, Brasil ${ }^{5}$ nnstituto de Química e Biotecnologia, Universidade Federal de Alagoas, Maceió, AL, Brasil
\end{abstract}

Infusions of Aspidosperma nitidum (Apocynaceae) wood bark are used to treat fever and malaria in the Amazon Region. Several species of this family are known to possess indole alkaloids and other classes of secondary metabolites, whereas terpenoids, an inositol and the indole alkaloids harmane-3 acid and braznitidumine have been described in A. nitidum. In the present study, extracts from the wood bark, leaves and branches of this species were prepared for assays against malaria parasites and cytotoxicity testing using human hepatoma and normal monkey kidney cells. The wood bark extracts were active against Plasmodium falciparum and showed a low cytotoxicity in vitro, whereas the leaf and branch extracts and the pure alkaloid braznitidumine were inactive. A crude methanol extract was subjected to acid-base fractionation aimed at obtaining alkaloid-rich fractions, which were active at low concentrations against $\mathrm{P}$. falciparum and in mice infected with and sensitive Plasmodium berghei parasites. Our data validate the antimalarial usefulness of $\mathrm{A}$. nitidum wood bark, a remedy that can most likely help to control malaria. However, the molecules responsible for this antimalarial activity have not yet been identified. Considering their high selectivity index, the alkaloid-rich fractions from the plant bark might be useful in the development of new antimalarials.

Key words: Aspidosperma nitidum - medicinal plants - human malaria - Plasmodium falciparum - selectivity index

Malaria affects millions of individuals in tropical and subtropical regions of the world and infection with Plasmodium falciparum continues to cause an economic burden in several areas (Sachs \& Malaney 2002) and to cause death among non-treated individuals, particularly children, non-immune travellers and pregnant women (WHO 2011). Approximately 219 million cases of malaria and 660,000 deaths were reported worldwide in 2010 (WHO 2012a).

Medicinal plants offer an alternative in treating malaria, particularly among populations exposed to endemic transmission in sub-Saharan African countries and in certain regions of Latin America (Bourdy et al. 2004, Willcox \& Bodeker 2004, Adebayo \& Krettli 2011, Adebayo et al. 2012). Although synthetic drug combinations

\footnotetext{
doi: 10.1590/0074-0276130246

Financial support: CNPq/FAPEMIG, MS (EMCT/CNPq 09/2009 - PRONEX Rede de Malária), CNPq (MCT/CNPq/CT-Saúde/MS/ SCTIE/DECIT 034/2008) (fellowships to JPC, ACCA and AUK) + Corresponding author: akrettli@cpqrr.fiocruz.br Received 6 May 2013

Accepted 17 October 2013
}

are the basis for malaria treatment in Brazil, plants are still used as remedies in the Amazon and elsewhere and represent a potential source for compounds in the development of new antimalarial drugs (Krettli 2009).

Due to the spread of drug-resistant parasites globally, the treatment of malaria is becoming increasingly difficult (WHO 2010). Thus, the identification of safe and selective antimalarial drugs derived from plants has been stimulated by the World Health Organization and is a research priority of several groups, including ours (Krettli et al. 2001, 2009, Aguiar et al. 2012a). Indeed, medicinal plants afforded the discovery in the XIX century of the first remedies from the bark of Cinchona spp, later shown to be rich in alkaloids, particularly quinine, the basis of such aminoquinoline synthetic drugs as chloroquine, amodiaquine and mefloquine. Another class of important antimalarials is based on artemisinin, a compound found in Artemisia annua, a medicinal plant native to China (WHO 2006). Unfortunately, clinical failures have also been reported in patients with $P$. falciparum treated with artemisinin derivatives in the recommended artemisinin combined therapy (WHO 2012b).

The testing of products from medicinal plants in animal models and in parasite cultures has resulted in the identification of potent molecules, as recently reviewed (Krettli et al. 2001, Krettli 2009, Aguiar et al. 2012b). 
An example is Cecropia pachystachya (Cecropiaceae), which is used against fever and malaria in several parts of Latin America, with tormentic acid and beta-sitosterol shown to be responsible for the antimalarial activity (Uchoa et al. 2010). Other examples include Aspidosperma nitidum (Benth) and Aspidosperma excelsum (Muell Arg), widely cited as remedies in the treatment of malaria, among other species of the genus Aspidosperma (Apocynaceae), which comprises various medicinal species used as bark infusions against malaria and other diseases (Brandão et al. 1992, Weniger et al. 2001, Ferreira et al. 2004, Tanaka et al. 2007, de Oliveira et al. 2011).

Reviews on the chemistry of Aspidosperma plants cite indole alkaloids (Pereira et al. 2007, Guimarães et al. 2012) and a new alkaloid, braznitidumine, from $A$. nitidum was described, isolated and characterised by one of the present authors (Meneses-Pereira et al. 2006). In this study, we verify the biological activity of wood bark extracts and fractions in vitro against chloroquineresistant (CQR) P. falciparum parasites and in a Plasmodium berghei-infected mouse malaria model.

\section{MATERIALS AND METHODS}

Plant materials - Wood bark, branches and leaves were harvested between 2004-2012 from the same adult tree (Fig. 1) growing at the Federal University of Amazonas farm located in Manaus, state of Amazonas, Brazil. A plant voucher coded 181832 has been deposited at the National Institute of Amazon Research herbarium. Using the plant material collected in 2004, a new alkaloid molecule named braznitidumine was previously described by one of the present authors (MMP) (MenesesPereira et al. 2006).

Extraction and chromatographic profiles of the active fractions - The materials of $A$. nitidum were dried, powdered and extracted using previously described protocols

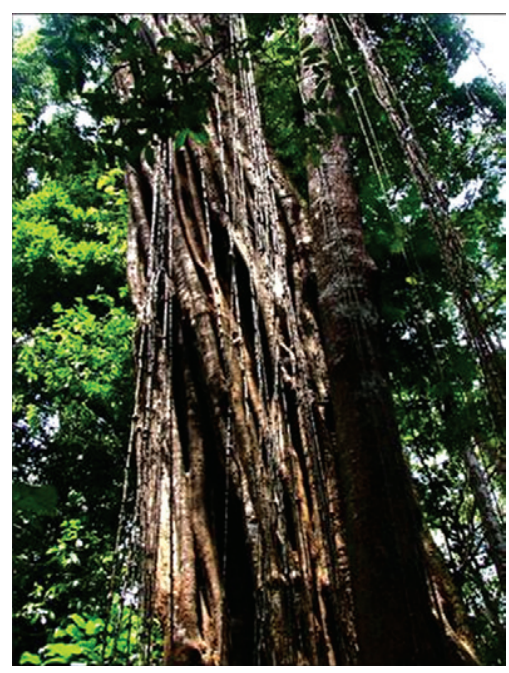

Fig. 1: Aspidosperma nitidum, a medicinal plant named carapanaúba, from which the wood bark material was collected and used to prepare extracts and fractions that displayed high antimalarial activity and low toxicity, in vitro and in vivo.
(Marques et al. 1996). The wood bark powder ( $2 \mathrm{~kg}$ ) was divided into two equal parts: one was extracted by static maceration with ethanol $(\mathrm{EtOH})$ for seven days at room temperature (RT) and the other with methanol $(\mathrm{MeOH})$. After solvent removal by rotary evaporation, $23.4 \mathrm{~g}$ $(2.3 \%)$ and $32 \mathrm{~g}(3.2 \%)$ of the $\mathrm{EtOH}$ and $\mathrm{MeOH}-\mathrm{A}$ crude extracts, respectively, were obtained. The EtOH crude extract and the chloroform and ethyl acetate fractions obtained were used for the biological tests described.

A new sample of wood bark $(1 \mathrm{~kg})$ was extracted with $\mathrm{MeOH}$ by maceration with agitation at $40^{\circ} \mathrm{C}$ for $48 \mathrm{~h}$ and yielded $34.4 \mathrm{~g}(3.4 \%)$ of the crude extract (MeOH-B). Extracts of the wood bark, leaves and branches were also prepared using either the Soxhlet technique (EtOH and acetone) or maceration at RT with agitation (EtOH and water).

The wood bark collected in $2012(1.5 \mathrm{~kg})$ was macerated at RT with $1.6 \mathrm{~L}$ of $\mathrm{MeOH}$ for $48 \mathrm{~h}$ to yield, after solvent removal, $85.5 \mathrm{~g}(5.7 \%)$ of $\mathrm{MeOH}-\mathrm{C}$ crude extract. This extract was then subjected to an acid-base fractionation protocol to obtain alkaloid-rich fractions (Fig. 2). The yields of each fraction are also shown in Fig. 2. The shaded box indicates the biological activity and positive reaction with Dragendorff's reagent.

The MeOH-C crude extract and its fractions (FO III, FO IV and precipitate) were subjected to a chromatographic analysis using a high performance liquid chromatography (HPLC) in with a Shimadzu apparatus (Shimadzu Co, Kyoto, Japan) composed by of a pump (model LC-10AD) and diode array detector (model SPDM20A) scanning from 200-500 nm, controlled by a CBM 20A. The sam-

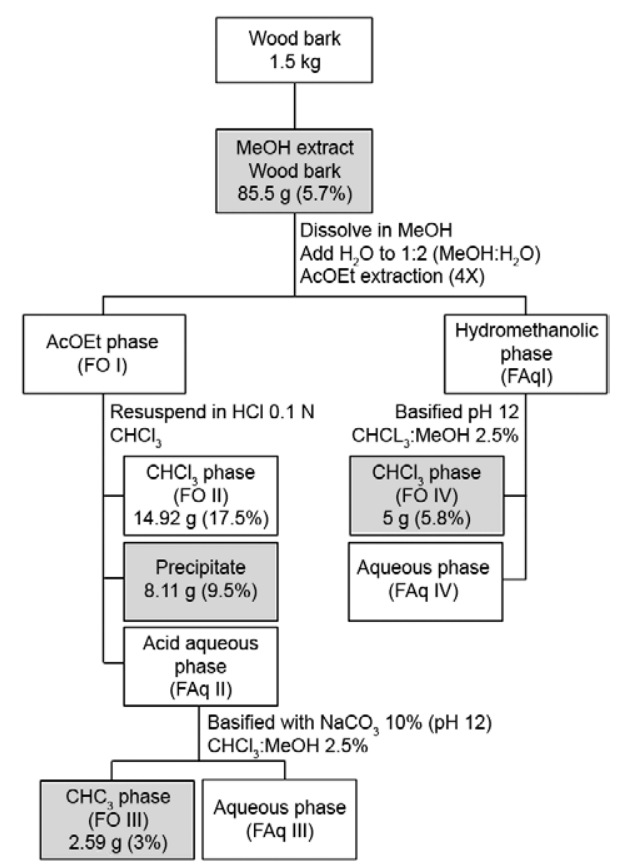

Fig 2: fractionation scheme of Aspidosperma nitidum methanolic wood bark extract and its fractions showing activity against malaria parasites highlighted in the boxes. AcOEt: ethyl acetate; $\mathrm{CHCl}_{3}$ : chloroform; $\mathrm{HCl}$ : hydrochloric acid; $\mathrm{MeOH}$ : methanol. 
ples were injected into a 20-1 loop coupled to a Rheodyne (IDEX Health \& Science, Oak Harbor, WA, USA) valve and analysis separated over with an Ascentis RP18 column (Supelco Inc, Bellefonte, PA, USA) with a particle size of 5 micrometers. The mobile phase was a: $\mathrm{MeOH}$-water (both with $0.1 \%$ formic acid) gradient from $30-50 \%$ in $20 \mathrm{~min}$, reaching $100 \% \mathrm{MeOH}$ at $25 \mathrm{~min}$. The data were acquired and analysed using the soft-ware LC-Solutions (Shimadzu North America, Columbia, MD, USA).

Antimalarial tests against $P$. berghei in mice - The protocol for animal use was approved by the Ethical Committee (CEUA LW-23/13) at the Oswaldo Cruz Institute.

A previously described antimalarial suppressive test in mice (Peters 1965) was slightly modified (Carvalho et al. 1991). Briefly, Swiss outbred adult female mice, $20 \pm 2 \mathrm{~g}$, were inoculated with $P$. berghei by an intraperitoneal route, $1 \times 10^{5}$ freshly infected red blood cells (iRBC) per animal, using either chloroquine-sensitive (CQS) (NK65) or CQR parasites selected by successive treatment (Krettli et al. 1969). Two-24 h later, the mice were randomly distributed and subjected to drug treatment by an oral route once a day for three consecutive days. Two control groups were used: one not treated and another treated with chloroquine (either $15 \mathrm{mg} / \mathrm{kg}$ for animals with CQS parasites or $100 \mathrm{mg} / \mathrm{kg}$ for animals with CQR parasites).

The plant extracts and fractions were freshly diluted with 3\% dimethyl sulphoxide (DMSO) in water immediately before gavage using different doses in a $200-\mu \mathrm{L}$ volume per animal. Blood smears were prepared at the fifth and seventh days after parasite inoculation, $\mathrm{MeOH}$ fixed, stained with Giemsa and examined microscopically for parasitaemia determination.

The inhibition of parasite growth (IPG) in the treated groups was evaluated by a comparison with the level of parasitaemia in the non-treated mice using the equation IPG $=100$ minus the mean parasitaemia in the treated mice, multiplied by 100 and divided by the mean parasitaemia in the non-treated controls. The compounds reducing parasitaemia by $40 \%$ or more were considered active, those reducing $30-40 \%$ as partially active and reductions of less than $30 \%$ as inactive.

Continuous cultures of P. falciparum and antiplasmodial tests - CQR and mefloquine-sensitive P. falciparum, clone W2 (Oduola et al. 1988), was cultivated using the candle jar method (Trager \& Jansen 1976), with minor modifications (Andrade-Neto et al. 2004). The continuous culture was maintained in human erythrocytes $\left(\mathrm{A}^{+}\right)$ at $37^{\circ} \mathrm{C}$ in complete medium (RPMI-1640 supplemented with $10 \%$ human sera blood group $\mathrm{A}^{+}$), which was changed daily. The human erythrocytes $\left(\mathrm{A}^{+}\right)$and serum blood group $\mathrm{A}^{+}$were kindly donated by the Centre of Haemotherapy and Haematology of Minas Gerais under a mutual cooperation agreement (protocol 18/09).

Immediately prior to the tests, the blood parasites were concentrated through sorbitol synchronisation of the ring stages (Lambros \& Vanderberg 1979). The blood suspension was adjusted for parasitaemia and haematocrit according to the specifications for each test, then distributed (180 $\mu \mathrm{L} /$ well) into 96-well microtitre plates
(Corning, Santa Clara, CA, USA) containing the diluted extracts, fractions and braznitidumine $(20 \mu \mathrm{L} /$ well $)$ in triplicate for each dose. Chloroquine, the standard antimalarial, was tested in parallel each time.

The activity of the plant extracts and fractions against $P$. falciparum was determined relative to the control cultures without antimalarial drugs as described (Rieckmann et al. 1978) and measured as follows: (i) the anti-HRPII test previously described (Noedl et al. 2002), (ii) the $\left[{ }^{3} \mathrm{H}\right]$ hypoxanthine incorporation assay (Desjardins et al. 1979) with slight modifications (Zalis et al. 1998) or (iii) quantitative tests based on optical microscopy, here referred to as the traditional test (Rieckmann et al. 1978).

For the anti-HRPII test, the P. falciparum cultures were adjusted to $1.5 \%$ haematocrit and $0.05 \%$ parasitaemia; anti-HRPII monoclonal antibodies were commercially acquired from ICLLAB (Stuart, FL, USA) (MPFM-55A and MPFG-55P) and the TMB chromogen (3,3',5,5'-tetramethylbenzidine) was acquired from KPL (Gaithersburg, MD, USA). After stopping the reaction with $50 \mu \mathrm{L} / \mathrm{L}$ of $1 \mathrm{M}$ sulphuric acid, the absorbance was measured at optical density (OD) $450 \mathrm{~nm}$ using a spectrophotometer (SpectraMax ${ }^{340} \mathrm{PC}^{384}$ ) (Molecular Devices, Sunnyvale, CA, USA).

For the $\left[{ }^{3} \mathrm{H}\right]$-hypoxanthine incorporation assay, $P$. falciparum cultures were maintained in a medium without hypoxanthine for at least four days and the haematocrit and parasitaemia were adjusted to $1 \% .\left[{ }^{3} \mathrm{H}\right]$-hypoxanthine $(0.5 \mu \mathrm{Ci})$ was acquired from PerkinElmer (Waltham, MA, USA). After $42 \mathrm{~h}$ of incubation with the drug, the cells were harvested [Tomtec 96-Harvester (Tomtec Inc, Handem, CT, USA)] on glass-fibre filters (Wallac Ou, Turku, Finland), placed in sample bags (Wallac) and immersed in scintillation fluid (Optiphase super mix, Wallac). The radioactive emission was counted using a 1450 Microbeta reader (Wallac).

For the traditional test, a suspension of RBCs with $1 \%$ parasitaemia, previously synchronised, was distributed into a 96-well microtitre plate $(100 \mu \mathrm{L} /$ well $)$ and cultured in complete medium (RPMI-1640 containing $10 \%$ human serum, $2 \%$ glutamine and $7.5 \% \mathrm{NaHCO}_{3}$ ). After $48 \mathrm{~h}$, blood smears were prepared, coded, stained with Giemsa and examined at 1,000X magnification. The parasitaemia of the controls (considered as $100 \%$ growth) was compared to that of the test cultures and the percentage IPG was calculated.

For all tests, the extracts and fractions were dissolved in aqueous DMSO $(0.02 \%)$ stock solution and the antiplasmodial activity was calculated by comparing the IPG in the drug-exposed cultures to that in the drug-free control culture. In tests performed using serial drug dilutions, sigmoid dose-response curves were generated with curve-fitting software (Microcal Origin Software v.5.0), which enabled the determination of the $50 \%$ inhibitory concentration $\left(\mathrm{IC}_{50}\right)$.

Cytotoxicity tests - The human hepatoma cell line (HepG2) was originally received from the New University of Lisbon and the monkey kidney cell line (BGM) was obtained from the Federal University of Minas Gerais. The cells were cultured in $75-\mathrm{cm}^{2}$ plates with 
RPMI-1640 medium supplemented with $10 \%$ heat-inactivated foetal calf serum and $40 \mathrm{mg} / \mathrm{L}$ gentamicin in a $5 \% \mathrm{CO}_{2}$ atmosphere at $37^{\circ} \mathrm{C}$. For the in vitro tests, a confluent cell monolayer was trypsinised, washed with culture medium, distributed in a flat-bottomed 96-well plate $\left(5 \times 10^{3}\right.$ cells/well) and incubated for $18 \mathrm{~h}$ at $37^{\circ} \mathrm{C}$ to ensure cell adherence.

Cytotoxicity was evaluated with the 3-(4,5-dimethylthiazol-2-yl)-2,5-diphenyltetrazolium bromide (MTT) (Denizot \& Lang 1986) assay. Briefly, the HepG2 and BGM cell lines were incubated with $20 \mu \mathrm{L}$ of the extracts and fractions at different concentrations $(1,000-15$ $\mu \mathrm{g} / \mathrm{mL}$ ) for $24 \mathrm{~h}$ in a $5 \% \mathrm{CO}_{2}$ and air atmosphere at $37^{\circ} \mathrm{C}$. For the MTT assay, which evaluates mitochondrial viability, $20 \mu \mathrm{L}$ of MTT solution $(5 \mathrm{mg} / \mathrm{mL})$ was added and the plates were incubated for another $3 \mathrm{~h}$. After incubation, the supernatant was carefully removed from the wells, followed by the addition of $100 \mu \mathrm{L}$ DMSO, with thorough mixing. The OD at $570 \mathrm{~nm}$ and $630 \mathrm{~nm}$ (background) was determined using an ELISA reader (SpectraMax ${ }^{340} \mathrm{PC}^{384}$ ).

The cell viability was expressed as the percentage of control absorbance obtained from the untreated cells after subtracting the absorbance from the appropriate background. The minimum lethal dose for $50 \%$ of the cells $\left(\mathrm{MLD}_{50}\right)$ was determined as previously described (Madureira et al. 2002). This value was used to calculate the selectivity index (SI) defined by the ratio between the $\mathrm{MDL}_{50}$ and $\mathrm{IC}_{50}$ values (Bézivin et al. 2003).

Statistical analysis - The data are expressed as the mean \pm standard deviation for the in vivo tests. The statistical significance of the survival curves was evaluated by an ANOVA test followed by a Bonferroni post-test and the mean parasitaemia by a Student's $t$ test followed by a Mann-Whitney $U$ post-test. Both analyses were performed using GraphPad Prism 5.0 software. Only $\mathrm{p}<0.05$ or less was considered statistically significant.

\section{RESULTS}

The plant material in the present study was collected between 2004-2012 from the A. nitidum specimen shown in Fig. 1. Extracts from the wood bark, leaves and branches were prepared and evaluated in biological assays with $P$. falciparum and mice infected with $P$. berghei in addition to assays to evaluate cytotoxicity. The EtOH crude extract of the wood bark collected in 2004 and its fractions, as obtained through liquid-liquid partitioning, were able to reduce the parasitaemia in mice infected with $P$. berghei by $55 \%$ (Table I). These are the same extracts and fractions used in a previous chemical investigation that resulted in the identification of several compounds, including harman-3-carboxylic acid and braznitidumine (Meneses-Pereira et al. 2006) which was inactive against $P$. falciparum in vitro (data not shown).

None of the crude extracts or fractions was cytotoxic to HepG2 or BGM cells; the $\mathrm{MDL}_{50}$ values of all the crude bark extracts and fractions were similar or better when tested on normal cells, with the exception of FO IV (Table II).

The crude plant extracts showed significant antimalarial activity. Thus, new plant material from this specimen was collected and extracts were prepared for further fractionation and in vitro tests against $P$. falciparum, as shown in Table III. The data showed that the A. nitidum crude extracts and fractions had similar $\mathrm{IC}_{50}$ values in the traditional test (data not shown), $\left[{ }^{3} \mathrm{H}\right]$-hypoxanthine incorporation and anti-HRPII test with monoclonal antibodies. The most active extracts were those obtained from the wood bark, whereas those from the branches and leaves were inactive or only slightly active $(\mathrm{EtOH}$

TABLE I

Parasitaemia and reduction in mice inoculated with Plasmodium berghei infected erythrocytes after oral treatment daily, for three consecutive days, with Aspidosperma nitidum ethanolic wood bark extract and its fractions

\begin{tabular}{|c|c|c|c|c|}
\hline \multirow{2}{*}{$\begin{array}{l}\text { Plant extract and ethanol fractions used } \\
\text { for mice treatment by oral route }{ }^{a}\end{array}$} & \multirow{2}{*}{$\begin{array}{c}\text { Dose } \\
(\mathrm{mg} / \mathrm{kg})\end{array}$} & \multicolumn{2}{|c|}{$\begin{array}{c}\text { Mice parasitaemia } \\
\mathrm{n}(\% \text { reduction })^{b}\end{array}$} & \multirow[b]{2}{*}{ Activity } \\
\hline & & Day 5 & Day 7 & \\
\hline Crude ethanolic extract & $\begin{array}{l}125 \\
250\end{array}$ & $\begin{array}{l}11(48) \\
11(48)\end{array}$ & $\begin{array}{l}25(49) \\
22(55)\end{array}$ & $\begin{array}{l}\text { Yes } \\
\text { Yes }\end{array}$ \\
\hline Chloroform fraction & $\begin{array}{l}125 \\
250\end{array}$ & $\begin{array}{l}17(19) \\
12(43)\end{array}$ & $\begin{array}{l}33(33) \\
18(63)\end{array}$ & $\begin{array}{l}\text { Partial } \\
\text { Yes }\end{array}$ \\
\hline Ethyl acetate fraction & $\begin{array}{l}125 \\
250\end{array}$ & $\begin{array}{l}18(14) \\
16(24)\end{array}$ & $\begin{array}{l}36(27) \\
30(39)\end{array}$ & $\begin{array}{c}\text { No } \\
\text { Partial }\end{array}$ \\
\hline Chloroquine (control drug) & 15 & $0(100)$ & $10(80)$ & Yes \\
\hline Non-treated & None & $21(0)$ & $49(0)$ & Control \\
\hline
\end{tabular}

$a$ : crude extract and fractions obtained through liquid-liquid partition (Marques et al. 1996) using the plant wood bark collected in 2004; $b$ : reduction of parasitaemia calculated in relation to control infected non-treated mice $(\mathrm{n}=3$ mice for treated groups and $\mathrm{n}=4$ mice for non-treated control group). 
crude extract of leaves) (Table III). The best activity was observed with the crude extracts from the wood bark, with $\mathrm{IC}_{50}$ values between $4.6-12.4 \mu \mathrm{g} / \mathrm{mL}$. The calculated $\mathrm{SI}$, a ratio between toxicity and activity in vitro, varied from 24-152.

The acid-base liquid-liquid partition of the $\mathrm{MeOH}-\mathrm{C}$ extract afforded three alkaloid-rich fractions (FO III, FO IV and precipitate) that were active against $P$. falciparum, with $\mathrm{IC}_{50}$ values as low as $1.6 \mu \mathrm{g} / \mathrm{mL}$ (for FO III). These fractions showed a positive reaction with Dragendorff's reagent and their analysis by HPLC-DAD confirmed the presence of braznitidumine in each (Fig. 3). Regardless of the in vitro assay used, the $\mathrm{IC}_{50}$ values were low, ranging from $1.6-5.5 \mu \mathrm{g} / \mathrm{mL}$ in the $\left[{ }^{3} \mathrm{H}\right]$-hypoxanthine assay, $2.3-7.6 \mu \mathrm{g} / \mathrm{mL}$ in the anti-HRPII assay and 2.8-6.8 $\mu \mathrm{g} /$ $\mathrm{mL}$ in the traditional test. None of the fractions was toxic to either HepG2 or BGM cells. Among the three fractions tested, the highest SI was found with the precipitate, which showed values of 200 in HepG2 and 364 in BGM cells in the [3H]-hypoxanthine assay and 145 (HepG2) and 263 (BGM) in the anti-HRPII assay (Table III).

\section{TABLE II}

Cytotoxicity of Aspidosperma nitidum extracts and fractions against a monkey kidney cell line (BGM) and a human hepatoma cell line (HepG2) determined by MTT expressed as the minimal lethal dose for $50 \%$ of cells $\left(\mathrm{MDL}_{50}\right)$

\begin{tabular}{|c|c|c|}
\hline \multirow[b]{2}{*}{ Crude extracts and fractions } & \multicolumn{2}{|c|}{$\begin{array}{c}\mathrm{MDL}_{50}(\mu \mathrm{g} / \mathrm{mL}) \\
\text { mean } \pm \mathrm{SD}\end{array}$} \\
\hline & BGM & HepG2 \\
\hline \multicolumn{3}{|l|}{ Bark extracts $^{a}$} \\
\hline Ethanolic & $\geq 2000$ & $654 \pm 40$ \\
\hline Methanolic-A & $964 \pm 1.4$ & $255 \pm 9$ \\
\hline Methanolic-B & $\geq 2000$ & $\geq 1000$ \\
\hline Methanolic-C & $427 \pm 243$ & $600 \pm 14$ \\
\hline \multicolumn{3}{|l|}{ Fractions from $\mathrm{MeOH}-\mathrm{C}^{b}$} \\
\hline Fraction FO III & $301 \pm 175$ & $62 \pm 18$ \\
\hline Fraction FO IV & $89 \pm 53$ & $169 \pm 50$ \\
\hline Precipitate & $\geq 2000$ & $1103 \pm 371$ \\
\hline \multicolumn{3}{|l|}{ Leaves extracts } \\
\hline Ethanolic & $\geq 2000$ & $\geq 1000$ \\
\hline Acetonic & $\geq 2000$ & $\geq 1000$ \\
\hline Aqueous & $\geq 2000$ & $\geq 1000$ \\
\hline \multicolumn{3}{|l|}{ Branches extracts } \\
\hline Ethanolic & $\geq 2000$ & $280 \pm 30$ \\
\hline Aqueous & $\geq 2000$ & $\geq 1000$ \\
\hline
\end{tabular}

$a$ : the different crude extracts were prepared from plant material by static maceration at room temperature [methanol ( $\mathrm{MeOH})-\mathrm{A}$ and $\mathrm{MeOH}-\mathrm{C}]$ or by maceration with agitation at $40^{\circ} \mathrm{C}$ (MeOH-B); $b$ : fractions from $\mathrm{MeOH}-\mathrm{C}$ were obtained through an acid-base liquid-liquid partitioning protocol to produce alkaloid-rich fractions (Fig. 2); MTT: (2-methoxy-4-nitro5-sulphophenyl)-2H-tetrazolium-5-carboxanilide; SD: standard deviation. Three tests were performed with each cell line.
The alkaloid-rich fractions were tested in mice infected with $P$. berghei and were active in two independent experiments (Table IV). The $\mathrm{MeOH}-\mathrm{C}$ crude extract reduced $P$. berghei parasitaemia by up to $67 \%$ with the dose of $100 \mathrm{mg} / \mathrm{kg}$; the FO III, FO IV and precipitate fractions, at $50 \mathrm{mg} / \mathrm{kg}$, also reduced parasitaemia by $66 \%, 65 \%$ and $57 \%$, respectively. Although a dose of $100 \mathrm{mg} / \mathrm{kg}$ decreased parasitaemia to a slightly reduced extent for unclear reasons, survival was significantly increased in the mice treated with the $\mathrm{MeOH}-\mathrm{C}$ crude extract and precipitate and in the mice receiving $50 \mathrm{mg} /$ $\mathrm{kg}$ of the FO III and FO IV fractions (Table IV).

In another independent experiment using mice infected with $P$. berghei CQR, the EtOH crude extract was protective at a dose of $125 \mathrm{mg} / \mathrm{kg}$, with the best results on the fifth day after inoculation, with $54 \%$ reduction in parasitaemia (Table V). Although chloroquine significantly reduced parasitaemia and increased survival, it was not curative in the mice treated with a high dose $(100 \mathrm{mg} / \mathrm{kg})$ compared with the untreated control mice (Fig. 4).

The potential of the active $\mathrm{MeOH}$ and $\mathrm{EtOH}$ crude wood bark extracts to induce mutagenic and genotoxic effects was evaluated with Ames tests (Ames et al. 1975). The tests were performed at the Genotox-Royal Institute, state of Rio Grande do Sul, Brazil (contract GT00752 and GT00719) using five strains of Salmonella typhimurium with different mutations at concentrations of up to $3,000 \mu \mathrm{g} /$ plate. The plant extracts were tested in the absence and presence of the metabolising rat liver fraction and none exhibited a potential for mutagenicity or genotoxicity.

\section{DISCUSSION}

Plants have been used throughout history as remedies in most cultures and are the basis for many pharmaceuticals currently in use. It is estimated that $80 \%$ of the tropical and subtropical populations of the world depend on herbal remedies to treat diseases and sources of new, safer and effective compounds with medicinal properties are investigated (Willcox et al. 2011). Several antimalarial formulated phytomedicines have been proposed as possible alternatives to costly and, therefore, unaffordable therapies (Willcox \& Bodeker 2004); however, this practice occurs to a lesser extent in Brazil, as the Ministry of Health provides specific diagnoses and synthetic antimalarials (portal.saude.gov.br/portal/arquivos/pdf/guia_pratico_tratamento_malaria_brasil_2602. pdf]. Nonetheless, several reference laboratories are located in and outside the malaria-endemic areas that are targeted for control (portal.saude.gov.br/portal/arquivos/ pdf/centros_de_referencia.pdf).

A recent broad compilation of plant species reported in the worldwide literature cites plants as treatments for fever and/or malaria and the names of 1,277 species in 160 families are listed; among these, 956 species belonging to 140 plant families are found in the Amazon alone (Willcox \& Bodeker 2004). In Brazil, a country with great biodiversity and rich ethnic and cultural diversity, the traditional knowledge of medicinal plants has been reported and medicinal plants have been investigated (Brandão et al. 1992, Andrade-Neto et al. 2007, Oliveira et al. 2009, 
Mota et al. 2012), as previously reviewed (Krettli et al. 2001, Krettli 2009, Aguiar et al. 2012a), constituting important sources that should be better explored.

Different native populations exposed to malaria transmission in the Amazon Region (including Brazil, Venezuela, Colombia and Guiana) and other Latin American countries use plant remedies as antimalarials, e.g., in Colombia (Garavito et al. 2006, López et al. 2009) and Bolivia (Muñoz et al. 2000) and among traditional healers in Brazil (Carvalho et al. 1991).

Among Aspidosperma species, A. excelsum and $A$. nitidum are widely cited as curative relative to fever and malaria (Brandão et al. 1992, de Oliveira et al. 2011) and communities living in areas of the state of Pará cite $A$. nitidum and $A$. rigidum (Rusby) and "Indian beer" or Ampelozyziphus amazonicus (Rhamnaceae) as antimalarials. Although "Indian beer" has been proven to act as a prophylactic in rodent malaria, in mice with sporozoite-induced infection and in vitro with sporozoite cultures (Andrade-Neto et al. 2008), its various crude extracts were clearly proven to be inactive against blood parasites in vitro and in vivo (Krettli et al. 2001). Crude extracts and fractions from other Aspidosperma species native to regions outside the malaria transmission area (in the state of Minas Gerais) have been proven to be active against malaria blood parasites (Oliveira et al. 2009,

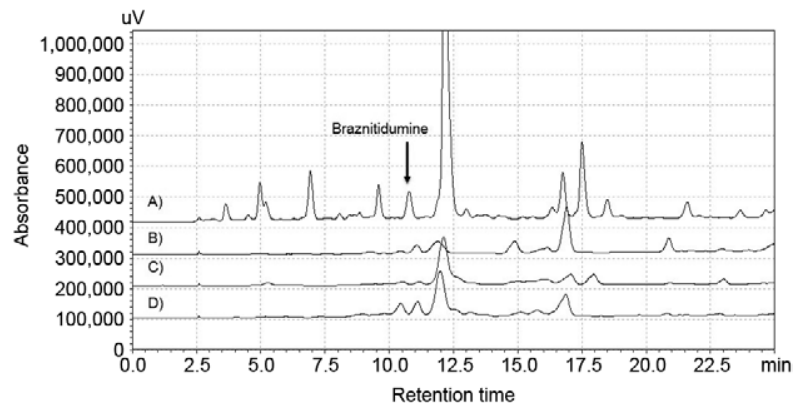

Fig. 3: extracted chromatograms comparison at $254 \mathrm{~nm}$ of $\mathrm{MeOH}$ crude extract (A) and fractions, precipitate (B), FO III (C) and FO IV (D).

Dolabela et al. 2012). Similarly, extracts from Aspidosperma vargasii and Aspidosperma desmanthum were also shown to be active and are believed to be a source of economically affordable drugs against malaria.

The present work confirms that crude extracts from the wood bark of $A$. nitidum show intense activity against malaria parasites in mice. Indeed, wood bark is the part of the plant used to prepare infusions to treat malaria in the Amazon Region. Based on our present results that the pure

\section{TABLE III}

In vitro activity of Aspidosperma nitidum extracts and fractions against Plasmodium falciparum blood forms measured as the dose inhibiting $50 \%$ inhibitory concentration $\left[\left(\mathrm{IC}_{50}\right)\right.$ in $\left.\mu \mathrm{g} / \mathrm{mL}\right]$ of parasite growth and selectivity index (SI), a ratio between cytotoxicity and activity [lethal dose for $50 \%$ of cells $\left(\mathrm{MDL}_{50}\right) / \mathrm{IC}_{50}$ ]

\begin{tabular}{|c|c|c|c|c|c|c|}
\hline \multirow{3}{*}{$\begin{array}{l}\text { Crude extracts } \\
\text { and fractions }\end{array}$} & \multicolumn{3}{|c|}{$\left[{ }^{3} \mathrm{H}\right]$-hypoxanthine } & \multicolumn{3}{|c|}{ Anti-HRPII } \\
\hline & \multirow{2}{*}{$\begin{array}{c}\mathrm{IC}_{50} \\
\text { mean } \pm \mathrm{SD}^{b}\end{array}$} & \multicolumn{2}{|c|}{$\mathrm{SI}^{a}$} & \multirow{2}{*}{$\begin{array}{c}\mathrm{IC}_{50} \\
\text { mean } \pm \mathrm{SD}^{b}\end{array}$} & \multicolumn{2}{|c|}{$\mathrm{SI}^{a}$} \\
\hline & & BGM & HepG2 & & BGM & HepG2 \\
\hline \multicolumn{7}{|l|}{ Bark extracts } \\
\hline Ethanolic & $7 \pm 3$ & 286 & 83 & $4.6 \pm 4.4$ & 435 & 126 \\
\hline Methanolic-A & $8.3 \pm 1.6$ & 116 & 31 & $10.7 \pm 1.3$ & 90 & 24 \\
\hline Methanolic-B & $10 \pm 3.6$ & 200 & 100 & $6.6 \pm 2.2$ & 303 & 152 \\
\hline Methanolic-C & $12.4 \pm 1.9$ & 34 & 48 & $10.8 \pm 0.4$ & 40 & 56 \\
\hline \multicolumn{7}{|c|}{ Fractions from $\mathrm{MeOH}-\mathrm{C}^{c}$} \\
\hline Fraction FO III & $1.6 \pm 0.06$ & 188 & 39 & $2.3 \pm 1.5$ & 70 & 30 \\
\hline Fraction FO IV & $3.3 \pm 0.4$ & 30 & 51 & $4.8 \pm 2.1$ & 19 & 35 \\
\hline Precipitate & $5.5 \pm 0.2$ & 364 & 201 & $7.6 \pm 4.4$ & 263 & 145 \\
\hline \multicolumn{7}{|l|}{ Leaves extracts } \\
\hline Ethanolic & $22 \pm 0.7$ & 91 & 29 & $25.3 \pm 6.0$ & 79 & 25 \\
\hline Acetonic & $\geq 50$ & \multicolumn{2}{|c|}{ Inactive } & $\geq 50$ & \multicolumn{2}{|c|}{ Inactive } \\
\hline Aqueous & $\geq 50$ & \multicolumn{2}{|c|}{ Inactive } & $\geq 50$ & \multicolumn{2}{|c|}{ Inactive } \\
\hline \multicolumn{7}{|l|}{ Branches extracts } \\
\hline Ethanolic & $\geq 50$ & \multicolumn{2}{|c|}{ Inactive } & $\geq 50$ & \multicolumn{2}{|c|}{ Inactive } \\
\hline Aqueous & $\geq 50$ & \multicolumn{2}{|c|}{ Inactive } & $\geq 50$ & \multicolumn{2}{|c|}{ Inactive } \\
\hline
\end{tabular}

$a$ : SI based on the results of cytotoxicity shown in Table II (SI $\leq 10$ is indicative of toxicity); $b$ : the samples considered active had IC $<12 \mu \mathrm{g} / \mathrm{mL}$ (partially active had $12-20 \mu \mathrm{g} / \mathrm{mL}$ and $>20 \mu \mathrm{g} / \mathrm{mL}$ were considered inactive); $c$ : fractions from methanol (MeOH-C) were obtained through an acid-base liquid-liquid partitioning protocol to produce alkaloid-rich fractions (Fig. 2); BGM: monkey kidney cell line; HepG2: hepatoma cell line. Three tests were performed with each methodology. 
TABLE IV

Antimalarial activity of Aspidosperma nitidum extracts and fractions from wood barks against Plasmodium berghei in mice in one experiment evaluated seven days after intraperitoneal infection induced by blood parasites

\begin{tabular}{lccc}
\hline $\begin{array}{l}\text { Mice group } \\
\text { treated with }^{a}\end{array}$ & $\begin{array}{c}\text { Dose } \\
(\mathrm{mg} / \mathrm{kg})\end{array}$ & $\begin{array}{c}\text { Parasitaemia } \\
\text { mean } \pm \mathrm{SD} \text { reduction })^{b}\end{array}$ & $\begin{array}{c}\text { Mice survival } \\
\text { in days } \\
(\text { mean } \pm \mathrm{SD})\end{array}$ \\
\hline $\begin{array}{l}\text { Non-treated } \\
\text { Treated with }\end{array}$ & None & $2.2 \pm 0.4$ & $22.8 \pm 2.7$ \\
MeOH-C $^{c}$ & 100 & $0.7 \pm 0.2(67)$ & $24.2 \pm 3.9^{d}$ \\
Fraction FO III & 50 & $0.7 \pm 0.3(66)$ & $21.4 \pm 2.3^{d}$ \\
& 100 & $1.1 \pm 0.6(48)$ & $22.8 \pm 5.0$ \\
Fraction FO IV & 50 & $0.8 \pm 0.2(65)$ & $21.4 \pm 2.3^{d}$ \\
& 100 & $1.0 \pm 0.9(54)$ & $23.0 \pm 4.5$ \\
Precipitate & 50 & $0.9 \pm 0.5(57)$ & $23.8 \pm 4.3$ \\
& 100 & $1.0 \pm 0.3(53)$ & $24.2 \pm 2.0^{d}$ \\
\hline
\end{tabular}

$a$ : treatment with extracts and fractions from the plant barks collected in 2012; $b$ : reduction of parasitaemia in relation to control untreated mice $(\mathrm{n}=5) ; c$ : fractions from methanol $(\mathrm{MeOH})-\mathrm{C}$ were obtained through an acid-base liquid-liquid partitioning protocol to produce alkaloid-rich fractions (Fig. $2) ; d: \mathrm{p}<0.05$ in relation to the non-treated control group; SD: standard deviation.

alkaloid braznitidumine described in the plant (MenesesPereira et al. 2006) was inactive in vitro, it is probable that a mixture of alkaloids detected in the active fractions of the crude extract of this plant are responsible for the antimalarial activity. New tests with braznitidumine need to be performed in mice, but this trial will require a large amount of this alkaloid, which is difficult to obtain.

In conclusion, the active $A$. nitidum crude bark extract showed the best activity against malaria parasites, the lowest cytotoxicity in vitro and no potential for mutagenicity or genotoxicity. Other species with proven antimalarial activity, such as Aspidosperma ramiflorum, Aspidosperma pyrifolium, Aspidosperma olivaceum, Aspidosperma macrocarpon and Aspidosperma tomentosum, have a lower therapeutic index, but have resulted in the chemical characterisation of new compounds systematically tested in vitro for anti-P. falciparum activity, with a low cytotoxicity and a less impressive therapeutic index (our unpublished observations). The alkaloids from several of these species have been characterised and shown to be active against Leishmania sp. parasites (Cunha et al. 2012). A. nitidum was by far the most active species, a finding that makes this traditional remedy useful for the control of malaria. However, further studies are required for drug development, as the present data indicate that the activity of the fractions and extracts may be due to a mixture of alkaloids rather than a single substance (braznitidumine). Nevertheless, drug mixtures are known to be important for delaying the appearance of drug-resistant malaria parasites.

\section{TABLE V}

Activity of ethanolic crude extract from wood bark of Aspidosperma nitidum against Plasmodium berghei chloroquineresistant in mice after treatment during three consecutive days in parallel with the antimalarial chloroquine

\begin{tabular}{lccc}
\hline & & \multicolumn{2}{c}{$\begin{array}{c}\text { Parasitaemia } \\
\text { mean } \pm \text { SD }\end{array}$} \\
& & \multicolumn{2}{c}{$(\% \text { reduction })^{a}$} \\
\cline { 3 - 4 } Treatment with & $\begin{array}{c}\text { Dose } \\
\text { (mg/kg) }\end{array}$ & Day 5 & Day 7 \\
\hline Control non-treated & 0 & $2.6 \pm 0.7(0)$ & $5.2 \pm 2.3$ \\
Chloroquine & 100 & $0.9 \pm 0.3(65)$ & $3.7 \pm 0.6(29)$ \\
EtOH crude extract & 62.5 & $1.8 \pm 0.5(31)$ & $3.9 \pm 0.2(25)$ \\
& 125 & $1.2 \pm 0.5(54)$ & $3.3 \pm 0.4(37)$ \\
& 250 & $1.4 \pm 1(46)$ & $4.8 \pm 1(8)$ \\
\hline
\end{tabular}

$a$ : reduction of parasitaemia calculated in relation to control infected non-treated mice $(\mathrm{n}=4)$; SD: standard deviation.
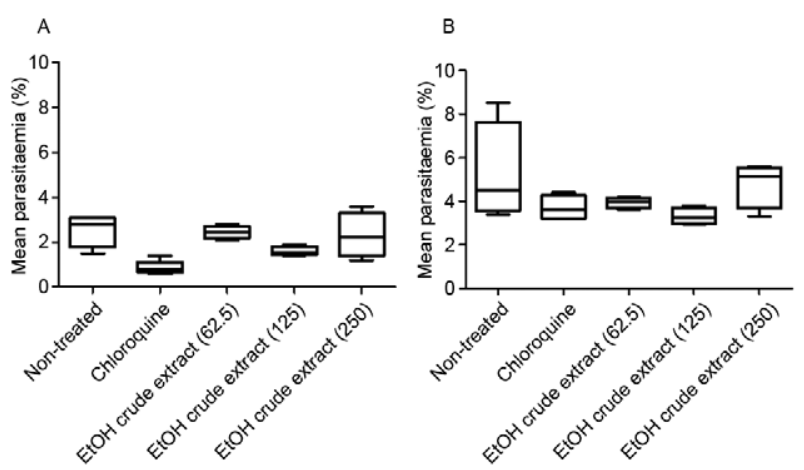

Fig. 4: mean parasitaemia by Plasmodium berghei in mice infected with chloroquine-resistant parasites following treatment for three consecutive days with the test compounds, evaluated on the fifth (A) and seventh (B) days after inoculation. EtOH: ethanol.

\section{ACKNOWLEDGEMENTS}

To Fiocruz, for providing logistics and facilities, and to the Department of Chemistry (ICEX/UFMG), for facilities provided to MMP during the initial studies of the plant species chemical characterisation.

\section{REFERENCES}

Adebayo JO, Krettli AU 2011. Potential antimalarials from Nigerian plants: a review. J Ethnopharmacol 133: 289-302.

Adebayo JO, Santana AEG, Krettli AU 2012. Evaluation of the antiplasmodial and citotoxicity potentials of husk fiber extracts from Cocos nucifera, a medicinal plant used in Nigeria to treat human malaria. Hum Exp Toxicol 31: 244-250.

Aguiar AAC, da Rocha EMM, de Souza NB, França TCC, Krettli AU 2012a. New approaches in antimalarial drug discovery and development - A Review. Mem Inst Oswaldo Cruz 107: 831-845.

Aguiar AAC, Santos RM, Figueiredo FJ, Cortopassi WA, Pimentel AS, França TC, Meneghetti MR, Krettli AU 2012b. Antimalarial 
activity and mechanisms of action of two novel 4-aminoquinolines against chloroquine-resistant parasites. PLoS ONE 7: e37259.

Ames BN, McCann J, Yamasaky E 1975. Methods for detecting carcinogens and mutagens with the Salmonella/mammalian-microssome mutagenicity test. Mutat Res 11: 347-364.

Andrade-Neto VF, Brandão MGL, Nogueira F, Rosário VE, Krettli AU 2008. Ampelozyziphus amazonicus Ducke (Rhamnaceae), a medicinal plant used to prevent malaria in the Amazon Region, hampers the development of Plasmodium berghei sporozoites. Int $J$ Parasitol 38: 1505-1511.

Andrade-Neto VF, Goulart MOF, da Silva Filho JF, da Silva MJ, Pinto MC, Pinto AV, Zalis MG, Carvalho LH, Krettli AU 2004. Antimalarial activity of phenazines from lapachol, beta-lapachone and their derivatives against Plasmodium falciparum and Plasmodium berghei in vivo. Bioorg Med Chem Lett 14: 1145-1149.

Andrade-Neto VF, Pohlit AM, Pinto ACS, Silva ECC, Nogueira KL, Melo MRS, Henrique MC, Amorim RCN, Silva LFR, Costa MRF, Nunomura RCS, Nunomura SM, Alecrim WD, Alecrim MGC, Chaves FCM, Vieira PPR 2007. In vitro inhibition of Plasmodium falciparum by substances isolated from Amazonian antimalarial plants. Mem Inst Oswaldo Cruz 102: 359-365.

Bézivin C, Tomasi S, Lohézic-Le Dévéhat F, Boustie J 2003. Cytotoxic activity of some lichen extracts on murine and human cancer cell lines. Phytomedicine 10: 99-503.

Bourdy G, Oporto P, Gimenez A, Deharo E 2004. A search for natural bioactive compounds in Bolivia through a multidisciplinary approach. Part VI. Evaluation of the antimalarial activity of plants used by Isoceño-Guaraní Indians. J Ethnopharmacol 93: 269277.

Brandão MGL, Grandi TSM, Rocha EMM, Sawyer DR, Krettli AU 1992. Survey of medicinal plants used as antimalarials in the Amazon. J Ethnopharmacol 36: 175-182.

Carvalho LH, Brandão MGL, Santos-Filho D, Lopes JLC, Krettli AU 1991. Antimalarial activity of crude extracts from Brazilian plants studied in vivo in Plasmodium berghei-infected mice and against Plasmodium falciparum in culture. Braz J Med Biol Res 24: 1113-1123.

Cunha AC, Chierrito TP, Machado GM, Leon LL, da Silva CC, Tanaka JC, de Souza LM, Gonçalves RA, de Oliveira AJ 2012. Anti-leishmanial activity of alkaloidal extracts obtained from different organs of Aspidosperma ramiflorum. Phytomedicine 19: 413-417.

de Oliveira DR, Costa A, Leitão GG, Castro NG, dos Santos JP, Leitão SG 2011. Ethnopharmacology study of saracuramirá (Ampelozizyphus amazonicus Ducke) in the "Quilombola" communities of Oriximiná, Pará state, Brazil. Acta Amaz 41: 383-392.

Denizot F, Lang R 1986. Rapid colorimetric assay for cell growth and survival. Modifications to the tetrazolium dye procedure giving improved sensitivity and reliability. J Immunol Methods 89: 271-277.

Desjardins R, Canfield C, Haynes J, Chulay J 1979. Quantitative assessment of antimalarial activity in vitro by a semiautomated microdilution technique. Antimicrob Agents Chemother 16: 710-718.

Dolabela MF, Oliveira SG, Peres JM, Nascimento JMS, Póvoa MM, Oliveira AB 2012. In vitro antimalarial activity of six Aspidosperma species from the state of Minas Gerais (Brazil). An Acad Bras Cienc 84: 899-910.

Ferreira ICP, Lonardoni MVC, Machado GMC, Leon LL, Gobbi-Filho L, Pinto LHB, de Oliveira AJB 2004. Anti-leishmanial activity of alkaloidal extract from Aspidosperma ramiflorum. Mem Inst Oswaldo Cruz 99: 325-327.

Garavito G, Rincón J, Arteaga L, Hata Y, Bourdy G, Gimenezc A, Pinzón R, Deharo E 2006. Antimalarial activity of some Colombian medicinal plants. J Ethnopharmacol 107: 460-462.
Guimarães HA, Braz-Filho R, Vieira IJC 2012. ${ }^{1} \mathrm{H}$ and ${ }^{13} \mathrm{C}-\mathrm{NMR}$ data of the simplest plumeran indole alkaloids isolated from Aspidosperma species: review. Molecules 17: 3025-3043.

Krettli AU 2009. Antimalarial drug discovery screening of Brazilian medicinal plants and purified compounds. Expert Opin Drug Discov 4: 95-108.

Krettli AU, Adebayo JO, Krettli LG 2009. Testing of natural products and synthetic molecules aiming at new antimalarials. Curr Drug Targ 10: 261-270.

Krettli AU, Andrade-Neto VF, Brandão MGL, Ferrari WMS 2001. The search for new antimalarial drugs from plants used to treat fever and malaria or plants ramdomly selected: a Review. Mem Inst Oswaldo Cruz 96: 1033-1042.

Krettli AU, Pereira JP, Brener Z 1969. Comparative study of experimental infections in mice inoculated with normal and chloroquine-resistant strains of Plasmodium berghei. Rev Inst Med Trop Sao Paulo 11: 94-100.

Lambros C, Vanderberg JP 1979. Sychronization of Plasmodium falciparum erythrocytic stages in culture. J Parasitol 65: 418-420.

López ML, Blair S, Sáez J, Segura C 2009. Effect of Solanum nudum steroids on uninfected and Plasmodium falciparum-infected erythrocytes. Mem Inst Oswaldo Cruz 104: 683-688.

Madureira MC, Martins AP, Gomes M, Paiva J, Proença da Cunha A, Rosário V 2002. Antimalarial activity of medicinal plants used in traditional medicine in S. Tomé and Príncipe islands. J Ethnopharmacol 8: 23-29.

Marques MFS, Kato L, Leitão Filho HF, Reis FAM 1996. Indole alkaloids from Aspidosperma ramiflorum. Phytochemistry 41: 963-967.

Meneses-Pereira M, Alcântara AFC, Pilo-Veloso D, Raslan DS 2006. NMR structural analysis of braznitidumine: a new indole alkaloid with 1,2,9-triazabicyclo [7.2.1] system, isolated from Aspidosperma nitidum (Apocynaceae). J Braz Chem Soc 17: 1274-1280.

Mota ML, Lobo LTC, da Costa JMG, Costa LS, Rocha HAO, e Silva LFR, Pohlit AM, de Andrade-Neto VF 2012. In vitro and in vivo antimalarial activity of essential oils and chemical components from three medicinal plants found in northeastern Brazil. Planta Med 78: 658-664

Muñoz V, Sauvain M, Bourdy G, Callapa J, Bergeron S, Rojas I, Bravo JA, Balderrama L, Ortiz B, Gimenez A, Deharo E 2000. A search for natural bioactive compounds in Bolivia through a multidisciplinary approach. Part I. Evaluation of the antimalarial activity of plants used by the Chacobo Indians. J Ethnopharmacol 69: 127-137.

Noedl H, Wongsrichanalai C, Miller R, Myint K, Looareesuwan S, Sukthana Y, Wongchotigul V, Kollaritsch H, Wiedermann G, Wernsdorfer W 2002. Plasmodium falciparum: effect of antimalarial drugs on the production and secretion characteristics of histidine-rich protein II. Exp Parasitol 102: 157-163.

Oduola AM, Milhous WK, Weatherly NF, Bowdre JH, Desjardins RE 1988. Plasmodium falciparum: induction of resistance to mefloquine in cloned strains by continuous drug exposure in vitro. Exp Parasitol 67: 354-360.

Oliveira AB, Dolabela MF, Braga FC, Jácome RLRP, Varotti FP, Póvoa MM 2009. Plant-derived antimalarial agents: new leads and efficient phythomedicines. Part I. Alkaloids. An Acad Bras Cienc 81: 715-740.

Pereira MM, Jácome RLRP, Alcântara AFC, Alves RB, Raslan DS 2007. Alcalóides indólicos isolados de espécies do gênero Aspidosperma (Apocynaceae). Quim Nov 30: 970-983. 
Peters W 1965. Drug resistance in Plasmodium berghei Vincke and Lips, 1948. I. Chloroquine resistance. Exp Parasitol 17: 80-89.

Rieckmann K, Campbell G, Sax L, Mrema J 1978. Drug sensitivity of Plasmodium falciparum. An in-vitro microtechnique. Lancet 1: 22-23.

Sachs J, Malaney P 2002. The economic and social burden of malaria. Nature 415: 680-685.

Tanaka JC, da Silva CC, Ferreira IC, Machado GM, Leon LL, de Oliveira AJ 2007. Antileishmanial activity of indole alkaloids from Aspidosperma ramiflorum. Phytomedicine 14: 377-380.

Trager W, Jensen JB 1976. Human malaria parasites in continuous culture. Science 193: 673-675.

Uchoa VT, de Paula RC, Krettli LG, Santana AEG, Krettli AU 2010. Antimalarial activity of compounds and mixed fractions of $\mathrm{Ce}$ cropia pachystachya. Drug Dev Res 91: 82-91.

Weniger B, Robledo S, Arango GJ, Deharo E, Aragon R, Muñoz V, Callapa J, Lobstein A, Anton R 2001. Antiprotozoal activities of Colombian plants. J Ethnopharmacol 78: 193.

WHO - World Health Organization 2006. Guidelines for the treatment of malaria, 2nd ed., WHO, Geneve, $210 \mathrm{pp}$.
WHO - World Health Organization 2010. Global report on antimalarial drug efficacy and drug resistance: 2000-2010, WHO, Geneve, $121 \mathrm{pp}$.

WHO - World Health Organization 2011. World Malaria Report 2011, WHO, Geneve, 3 pp.

WHO - World Health Organization 2012a. World Malaria Report 2012, WHO, Geneve, 195 pp.

WHO - World Health Organization 2012b. Update on artemisinin resistance. Global Malaria Programme, WHO, Geneve, 10 pp.

Willcox M, Benoit-Vical F, Fowler D, Bourdy G, Burford G, Giani S, Graziose R, Houghton P, Randrianarivelojosia M, Rasoanaivo P 2011. Do ethnobotanical and laboratory data predict clinical safety and efficacy of anti-malarial plants? Malar J 10 (Suppl. 1): S7.

Willcox M, Bodeker G 2004. Traditional herbal medicines for malaria. BMJ 329: 1156-1159.

Zalis MG, Pang L, Silveira MS, Milhous WK, Wirth DF 1998. Characterization of Plasmodium falciparum isolated from the Amazon Region of Brazil: evidence for quinine resistance. Am Soc TropMed Hyg 58: 630-637. 